\title{
Perspektywy renesansu publicznego stosowanej pedagogiki społecznej w postindustrialnej przestrzeni
}

\begin{abstract}
Perspectives of a Public Renaissance in Applied Social Pedagogy In Postindustrial Space
Abstract

The author takes up a critical approach to several concepts presented in the literature of social sciences, on so expected problems of public rehabilitation and revitalisation during the active enggement of such subdiscipline as modern social pedagogy. He analyses the local urban space, opposed to spontaneoulness chaos and anomia accured in public structures. The paper warns againt the relinquishment in local communities of earlier order and the whole social network. It could becme in each posttransformated cociety during the social change. The aim of the paper was to mobilise on future a public support across education and prophylaxis to avoid a lot of individual and collective traumatic and neurostic feelings.
\end{abstract}

\section{Keywords}

renaissance, applied social pedagogy, postindustrial space, future of public rehabilitation, social network

Przedstawiając pedagogom społecznym - na łamach nowego czasopisma - szczegółowe problemy o istotnym znaczeniu, o których rzetelna wiedza może przyczynić się do pomyślnego wykonywania zadań cząstkowych podczas przebiegu pracy zawodowej prowadzonej w obszarze egzystencji społeczności lokalnej, przedstawię zarówno ogólne ramy, jak i poszczególne elementy funkcjonowania civil society we współczesnym państwie demokratycznym w sferze teorii i praktyki. Taka zasadność istnieje wobec regresu instytucjonalnych środków demokracji partycypacyjnej nastałych w otaczającym nas ładzie polityczno-ideologicznym oraz ekonomicznym. Aktualne na dziś pozostają pytania, czy w ogóle, a jeśli tak, to w jaki sposób można: 
- zagwarantować społecznościom lokalnym podejmowanie ostatecznych rozstrzygnięć we wszelkich kwestiach wiążących się z organizacją życia na ich terenie, przy równoczesnym wykorzystywaniu środków z puli centralnej (państwowej)?

- co zrobić, by nadal - jak dotychczas - prolongować państwu strukturalną szansę na racjonalne podejmowanie decyzji, które nie są możliwe bez odpowiedniego społecznie upoważnienia do ingerencji w jego społeczny kontekst działania o znaczącym i prawnie obwarowanym zastrzeżeniu po 2015 roku dotyczącym współdecydowania władz i obywatelskich struktur lokalnych przy podejmowaniu ostatecznych decyzji ${ }^{1}$.

Wiąże się z tym kolejny problem, czy i na ile dynamice opierania politycznych decyzji na rozwijającej się wiedzy przy równoczesnej polityzacji problemów nauki będą mogły jeszcze odpowiadać racjonalne i koherentne struktury społeczeństwa i państwa ${ }^{2}$. Niestety, na te pytania Czytelnicy będą musieli uzyskać odpowiedzi sami, jeszcze nie w chwili obecnej, ale zapewne na przestrzeni kilku kolejnych lat, decydujących ostatecznie o trendach rozwoju współczesnego społeczeństwa obywatelskiego w Polsce. Społeczeństwo obywatelskie w naszym kraju znajduje się niestety wciąż na etapie tworzenia, a więc powstawania, zmiany czy prób konsolidacji. Jest to proces skomplikowany, wielopostaciowy i rozłożony w czasie. Procesy decentralizacji oraz pierwsze objawy integracji powinno się rozpatrywać nie w doraźnej, lecz w dalszej perspektywie czasowej. Niewątpliwie na przestrzeni ostatniej i bieżącej dekady pojawiły się już pewne symptomy kształtowania się tego typu społeczności. Można zatem przejawiać wyłącznie nadzieję - jak zawsze w świetle naszych doświadczeń - że dalsze przemiany przebiegać będą w kierunku tworzenia demokracji partycypacyjnej oraz zmierzać ku wyłanianiu odpowiedzialnego (świadomego swych praw i obowiązków) nowoczesnego, otwartego i aktywnego społeczeństwa ${ }^{3}$. Z tych też względów $\mathrm{w}$ tej części nawiązujemy do bezpośrednich doświadczeń jednostki, które w przekonaniu ekspertów właśnie w okresie postpandemicznej transformacji będą wymagać skoncentrowanej uwagi.

Na wstępie artykułu dobrze byłoby - tak sądzę - zarysować chociażby bardzo ogólnie kilka pojęć nawiązujących tematycznie do tytułu i zawartości niniejszego opracowania. Pierwszym z nich pozostaje pojęcie renesansu, niewymagające wszakże precyzyjnego i szczegółowego wyjaśnienia. Renesans (fr. renaissance to

${ }^{1} \mathrm{~K}$. Segiet, O społecznościach lokalnych $i$ wspólnotach ludzkich $w$ warunkach globalizacji - perspektywa pedagogiczna, „Kultura - Społeczeństwo - Edukacja” 2020, nr 1 (17), s. 7-26. Por. A. Radziewicz-Winnicki, Pedagogika społeczna, Warszawa 2008, s. 364-365.

${ }^{2}$ R. Schmalz-Bruns, Civil Society-ein postmodernes konstprodukt? Eine Antwort auf volker Heins, „Politische Vierteljahresschrift”, 1992 (33), z. 2. s. 235-242.

${ }^{3}$ M. Jóźko, Społeczeństwo obywatelskie w małym mieście, „Kultura i Społeczeństwo” 2002, nr 3, t. XLVI, s. 148. 
odrodzenie) utożsamiany jest na świecie z kreatywną epoką ram czasowych wieku XVI, wyraźnie wyróżniający się w kulturze, nauce, sztuce oraz wypierający (chociaż nie do końca) tradycyjnie zakorzenione publicznie, a w zasadzie wszechobecne formy średniowiecza. Idee renesansowe często nawiązywały $\mathrm{w}$ wielu kontekstach do antycznej starożytności (np. w architekturze, malarstwie, literaturze, filozofii i kulturze intelektualnej), propagującej tzw. humanizm renesansowy $y^{4}$. Dla mnie kojarzy się on niezmiennie ze współczesnym rozumieniem rehabilitacji i rewitalizacji społecznej na tle egzystującej anomii publicznej. Towarzysząca naszej egzystencji anomia w koncepcji sformułowanej po raz pierwszy przez Émile’a Durkheima to stan zagubienia, szczególne poczucie bezradności powstałe w wyniku osłabienia oddziaływania lub rozpadu norm, w jakich może znaleźć się dana grupa społeczna (społeczeństwo), na skutek załamania się porządku społecznego (wojna, rewolucja, kryzys publiczny). Wynika ona z braku równowagi pomiędzy kulturowo określonymi celami a zdefiniowanymi jako prawomocne, zinstytucjonalizowane, możliwe w danej chwili sposoby osiągnięcia tychże celów ${ }^{5}$. Oznacza ono najczęściej zaburzenie struktury jednostki w trakcie rutynowych sposobów jej postępowania, skali oczekiwań i aspiracji, wzorów konsumpcji itp. przemawiających na rzecz społeczeństwa zintegrowanego.

Rehabilitacja społeczna ${ }^{6}$, w prawnym i społecznym kontekście oznacza przywrócenie utraconego stanu równowagi (ale również odzyskanie uprzednio nabytych praw i innych możliwości, przyzwoleń). To jednoczesne stosowanie w pedagogice społecznej oraz specjalnej odpowiednich intencjonalnych zabiegów (działań, dyrektyw socjotechnicznych) na rzecz kompensacji. Przywracanie sprawności fizycznej bądź to psychicznej (indywidualnej lub zbiorowej) za pomocą przygotowanego uprzednio programu wsparcia pomocowego, np. terapeutycznego. Proces rewitalizacji (oznaczający dosłownie ożywienie, ponowne przywrócenie do życia, waloryzowanie) utożsamiany jest $\mathrm{z}$ wprowadzeniem nastałej sytuacji, stanu kryzysowego, chaosu, zdegradowanych elementów przestrzeni publicznej (miasta, społeczności zmarginalizowane czy to już wykluczone). Rewitalizacja (łac. re-vita; ang. revitalisation, urban reneval) to zespół spójnych na rzecz homeostazy, powiązanych ze sobą oddziaływań intencjonalnych. To proces polegający na prze-

${ }^{4}$ Odrodzenie, [w:] Encyklopedia Powszechna PWN, Warszawa 1982, s. 536; zob. Z. Hull, Wstęp. W poszukiwaniu prawdy o człowieku, [w:] W. Tulibacki, Z. Frydryszek (red), O literaturze i filozofii. Problemy - Twórcy - Dzieła, Olsztyn 1999, s. 9-13.

${ }^{5}$ Przytaczam za: P. Sztompka, Socjologia. Analiza społeczeństwa, Kraków 2002, s. 275 i następne. Por. A. Radziewicz-Winnicki, Pedagogika społeczna, op. cit., s. 596.

${ }^{6}$ B. Szacka, Wprowadzenie do socjologii, Warszawa 2003, s. 33; zob. M. Mendel, W. Theiss, Pamięć i miejsce „in potentia”: o mieście pełnym, „Pedagogika Społeczna” 2016, nr 1 (59) s. 63. Por. J. Modrzewski, Z(dez)integrowane społeczeństwa - istota zjawiska i problemu w perspektywie strukturalno-funkcjonalnej, „Pedagogika Społeczna” 2017, nr 4 (66), s. 15-36; zob. A. Radziewicz-Winnicki, Pedagogika społeczna, op. cit., s. 513-519 i inni. 
mianie zdegradowanych obszarów (najczęściej odwołują się teoretycy, urbaniści do miejskich struktur przestrzennych). Dotyczy ona również poprawy estetyki, wygód dla jej użytkowników, słowem jakości życia, w odmienionej już, a więc zrewitalizowanej przestrzeni, w której diagnozowane były uprzednio również rodzaje potrzeb i oczekiwania jednostek oraz szerszych grup społecznych ${ }^{7}$.

Rehabilitacja i rewitalizacja pojawiają się jako swoiste przeciwdziałania - nieomal historycznie już dostrzeganej sprzeczności - pomiędzy elementami kultury a działaniem wielu mechanizmów struktury społecznej, sprawczo wywołujących patologię oraz liczne dewiacje społeczne. Według greckiego źródłosłowia anomia, o której sygnalizowano już wcześniej, to postępowanie niezgodne z prawem, nierząd albo też życie nierządne, pozbawione godnych przykładów czy reguł, które można by zalecać $\mathrm{w}$ życiu publicznym do powszechnego postępowania tudzież internalizacji. Takim przykładem jest właśnie eunomia - jej praktyczne urzeczywistnienie oznaczające zadawalający i oczekiwany - zdaniem Krystyny Szafraniec - stan publicznego ładu społecznego, pożądany przypadek rzeczy, sytuacja powszechnego przez obywateli respektowania i postrzegania porządku prawnego, przeciwstawiająca się chaosowi, rozregulowaniu czy to dezintegracji ${ }^{8}$. Sprzyjać będzie ona niewątpliwie spoistości egzystujących struktur publicznych. Zaniknąć wówczas powinien ujawniający się kryzys (nieufność) w stosunku do instytucjonalnie uprawnianej na bieżąco polityki społecznej, a co więcej, być może nastąpiłby wówczas wzrost sporej części społeczeństwa ku paradygmatowi dalszego rozwoju endogennego, polegającego m.in. na przekonaniu, iż zaufanie czy współpraca (tak formalna, jak i nieformalna) stanowią kluczowy element budowania kapitału społecznego, bez którego akceleracja zjawisk rozwojowych staje się prawie niemożliwa. W rezultacie, tak jak obecnie, mamy do czynienia z krytyczną oceną w świadomości publicznej rodaków, dyskusją nad niewielkim zaangażowaniem, mającym głównie charakter niszowy i wyjątkowo elitarny ${ }^{9}$. Sytuacja, do której będę także pokrótce nawiązywał, dotyczy społeczeństwa postindustrialnego, które

7 T. Wilk, „Rewitalizacja społeczna poprzez wspótczesna sztukę teatralna w ocenie reprezentantów (twórców i odbiorców) sztuki dramatycznej Legnicy, Nowej Huty, Wałbrzycha, Katowice 2010, s. 31; zob. B. Smolińska-Theiss, Pedagogika społeczna - pedagogika społecznie zaangażowana wokót inicjatyw i ruchów społecznych, „Pedagogika Społeczna” 2018, nr 4 (70), s. 10-13.

${ }^{8}$ K. Szafraniec, Anomia, [w:] Encyklopedia Socjologii, t. 1, Warszawa 1998, s. 32. Por. A. Matysiak-Błaszczyk, J. Modrzewski (red.), Socjalizacja dysocjacyjna $w$ doświadczeniu indywidualnym i społecznym. Inspiracje teoretyczne i próby pedagogicznych ingerencji, Poznań-Kalisz 2012.

${ }^{9}$ D. Krysiński, J. Banaś, Między nieudaną prowokacją a modelowa integracją. O renesansie aktywizacji społecznej w wydaniu artystycznym, „Kultura i Społeczeństwo” 2018, nr 3, t. LXII, s. 83; zob. K. Podemski, Społeczeństwo obywatelskie w Polsce 25 lat po wielkiej zmianie, „Ruch Prawniczy, Ekonomiczny i Socjologiczny” 2014, z. 2. Por. J. Modrzewski, A. Matysiak-Błaszczyk, W. Włodarczyk (red), Środowiska uczestnictwa społecznego jednostek, kategorii i grup (doświadczenia socjalizacyjne i biograficzne), Poznań 2018. 
to pojęcie utożsamiane jest $\mathrm{z}$ jego rozwojowym najwyższym stadium społeczeństwa industrialnego (często zamiennie określanym jako społeczeństwo informacyjne/informatyczne). Charakteryzuje się ów etap rozwoju wysoce zaangażowanym rozwojem socjoekonomicznym poszczególnych struktur społecznych, a także ewolucją informatyki, sieci telekomunikacyjnych, kontrolowaniem biurokracji przez profesjonalnych menedżerów, dużą transparentnością działania, stabilnością i pluralizmem. O rozwoju niektórych takich społeczeństw teoretycy w naukach społecznych wspominają począwszy od lat 60 . ubiegłego wieku. Napomknąć wypada, iż w Polsce nieustannie mamy do czynienia z próbami modernizacji tradycyjnego społeczeństwa, a przynajmniej pewnych jego społeczności. Od wielu lat, zdaniem ekspertów (ale także neoliberalnych polityków), państwa rozwijające się winny pilnie się reformować, modyfikując polityczną i społeczną (często zacofaną) organizację, wyzwalając się spod wielowiekowej tradycji. Rezultatem owych ideologicznych poczynań miał być oczekiwany przez rzeczników modernizacji samoczynny wzrost gospodarczy, dobrobyt, realna suwerenność i zadawalająca jakość życia. Towarzyszyć im powinien stały rozwój społeczeństwa obywatelskiego. Modelowego wzoru dla wszczynanych reform publicznych miały dostarczyć kraje zamożne i bardzo wysoko rozwinięte, wywodzące się głównie z europejskiego kręgu kulturowego, Ameryki Północnej, Australii i Nowej Zelandii ${ }^{10}$. Zaczęto też tworzyć modelowe wizje, wzory idealne tzw. społeczeństwa tradycyjnego ustępującemu miejsca społeczeństwu nowoczesnemu, idealnemu. Starano się przy tym zaprezentować typowe relacje występujące $\mathrm{w}$ obrębie dotychczasowego podziału poszczególnych struktur publicznych. Pamiętać przy tym należy, iż stosowano wiele uproszczeń, a także często fałszywych wyobrażeń o rychłej możliwości przekształcenia otaczającej indywiduum rzeczywistości w programach psychospołecznej interwencji, na rzecz modernizowania społeczności lokalnych/regionalnych, jak i ponadregionalnych ${ }^{11}$.

Zanim przystąpię do głównej narracji nakreślonej autorskiej wizji dalszych tendencji rozwojowych współczesnej pedagogiki społecznej, jak i „pedagogiki współbycia", tj. propozycją społeczeństwa współdziałającego lansowaną - słusznie i trafnie - przez Katarzynę Segiet ${ }^{12}$, pragnę przedłożyć wnikliwym Czytelnikom tomu jeszcze tylko skromne refleksje związane z zapowiedzią tematyczną Zespołu Redakcyjnego. Cały, odmieniony obecnie układ strukturalny czasopisma edytowanego począwszy od 2021 roku, można w przybliżeniu traktować jako ważne

${ }^{10}$ K. Krzysztofek, M.S. Szczepański, Rozwój społeczny. Trzy paradygmaty, „Kultura i Społeczeństwo" 1987, nr 3, t. XXI, s. 45-46. Por. A. Radziewicz-Winnicki, Pedagogika społeczna, op. cit., s. $259-281$.

${ }^{11}$ K. Segiet, O społecznościach..., op. cit., s. 9-10; por. A. Radziewicz-Winnicki, Pedagogika społeczna, op. cit., s. 267-271.

${ }^{12}$ K. Segiet, O społecznościach..., op. cit., s. 13-14. 
przybliżenie wielu wątków problemowych (z jednej strony), wymagających adekwatnego rozstrzygnięcia w naukach społecznych nie tylko w Polsce. Z kolejnej, metaforycznej, (drugiej) strony celem pierwszego numeru periodyku jest także wyzwanie ku zarówno rozwojowi, jak i reinterpretacji przez rzeczników współczesnej polskiej pedagogiki społecznej specyficznej perspektywy analizy zadań wiążących się z kreowaniem przestrzeni egzystencji życiowej ${ }^{13}$. Zakłada się, iż uwzględniać ona powinna ideologię naszej subdyscypliny wdrożoną właśnie w przestrzeni miejskiej w społeczeństwie postindustrialnym ${ }^{14}$. Wszakże przestrzeń obok czasu jest najbardziej uniwersalnym wymiarem życia ludzkiego. Nie da się ludzkiej egzystencji oddzielić od pojęcia przestrzeni. Z kolei bardzo trudno ją analizować. Od czasu Émile’a Durkheima i Maxa Webera powstało mnóstwo fragmentarycznych teorii usiłujących opisać mechanizmy wpływające na człowieka w przestrzeni ${ }^{15}$.

I ostatnia uwaga. Nie przewidujemy w trakcie analiz jakiegokolwiek naruszenia przestrzeni osobistej (ang. personal space), która stanowi obszar najbliższy ciału człowieka, przyrównywany do niewidzialnej „proksemiotycznej bańki” (ang. proxemic bubble) otaczającej człowieka i przemieszczającej się wszędzie wraz z danymi osobnikami. Stanowi ona wówczas - według J. Altemana - bufor zabezpieczający istotę ludzką przed jakimkolwiek zagrożeniem fizycznym bądź emocjonalnym (np. fizyczny atak, przemoc ze strony zewnętrznej, ale również stresowe pobudzenie $)^{16}$. Rozważania przedłożone $\mathrm{w}$ niniejszym tekście dotyczą sytuacji przebiegającej w przestrzeni publicznej/społecznej, umożliwiającej korzystanie przez osobnika $z$ wielu przedstawionych ofert sprzyjających/pobudzających wyzwalaniu się szeregu często niedostępnych i nieznanych uprzednio jednostkom interakcji publicznych.

Na podstawie wyszczególnionych (przyjętych) założeń, w kolejnym, głównym fragmencie artykułu, postaram się prowadzić rozważania o dalszej perspektywie bieżącej i następującej po niej dekadzie - wrastania pedagogiki społecznej w kulturową i organizacyjną jedność (wspólnotę) nauk społecznych, wskazywać na elementy ciągłości, ale również prawdopodobnej modyfikacji celów, uwypuklając

${ }^{13}$ K. Kurnicki, Ideologie w mieście: o społecznej produkcji przestrzeni, Kraków 2018.

14 A. Harding, T. Blaxland, Urban Theory. A Critical Introduction to Power, Cities and urbanism in $21^{\text {st }}$ Century, Los Angeles-London-New Delhi-Singapore-Washington DC 2014, s. 19; zob. W. Theiss, Radlińska, Warszawa 1997, s. 79.

15 M. Cobel-Tokarska, Przestrzeń społeczna: świat - dom - miasto, Warszawa 2011, s. 6-7. Por. A. Szczurek-Boruta, B. Chojnacka- Synaszko, J. Suchodolska (red.), Człowiek w przestrzeni lokalnejdobre praktyki wspierania rozwoju, aktywizacji i integracji społecznej, Toruń 2014.

${ }_{16}$ J. Alteman, The Environment of social Behaviour, Monterey 1971. Przytacza: J.F. Jacko, Nimb aksjologiczny. Uwagi o etycznych aspektach przestrzeni osobistej, „Ethos” 2013, nr 4, s. 148-149. 
tym samym bogatą refleksyjność tej dziedziny wiedzy ${ }^{17}$. Podobnie jak współczesna oświata dorosłych bądź, ujmijmy to szerzej, jak większość współczesnych subdyscyplin rodzimej pedagogiki, oparta jest ona na paradygmacie rozwoju przemysłowego i socjokulturowej modernizacji, promujących ucywilizowany prozachodni model racjonalności i indywidualnej samorealizacji. Stanowić może również w pewnych obszarach ludzkiej uniwersalnej wspólnoty, przejaw siły i dynamiki rozwoju, m.in. poprzez aktywne (jednostek i grup) masowe uczestnictwo społeczne. Koncentruje się bowiem zarówno na celach indywidualnych, jak i zbiorowych, wśród których dominują (dominować będą) m.in. osobowa samorealizacja oraz kompetencje umożliwiające (ułatwiające, sprzyjające) przetrwanie w dynamicznie zmieniającej się rzeczywistości oraz na coraz to bardziej wymagającym i trudnym rynku pracy. Ponadto dostarcza wiedzy i argumentów na rzecz modernizowania, a nawet zmieniania otaczających osobnika struktur ${ }^{18}$. Pedagogika społeczna uznaje, iż trwałym czynnikiem rozwoju są konstruowane (nie tylko w teorii, ale i w praktyce społecznej) ideały. Alienujące się często instytucje społeczne nie stanowią nigdy stabilnych, choćby tylko historycznie już ustanowionych i w miarę trwałych struktur, które pozostają formami zbiorowego działania społecznego. Jeśli dostrzegamy jakiekolwiek uchybienia czy niedorzeczności w stawianych diagnozach, a następnie podejmowanych (czy też zaledwie propagowanych) rozstrzygnięciach o charakterze wadliwych i błędnych przekonań, niekompetencji tworzących realia naszej rzeczywistości (a jest nim niewątpliwie deficyt racjonalnie wyzwalanych pomysłów i doradztwa zdecenralizowanego na miarę potrzeb polityki ekonomicznej i społecznej we współczesnych strukturach - nie zawsze - obywatelskich, które mogłyby uelastycznić tradycyjny archetyp organizacyjnego działania), to główny powód upatrywać należy w niewysokim niestety wskaźniku osób legitymizujących się wykształceniem wyższym w naszym kraju. Konsekwencje tego stanu rzeczy są oczywiste, determinujące je nagminnie występujący przejaw przerażająco ubogiej wiedzy ogólnej o dokonanych i aktualnie przebiegających w świecie przeobrażeniach i prawach rozwoju demokratycznych społeczeństw o wysoko rozwiniętej gospodarce rynkowej. Nie ukrywam, że fakt ów zdecydował również (i to w znacznej mierze) o podjęciu starań wiążących się z przygotowaniem niniejszego artykułu. Fragmentaryczny opis zmieniającej się w naszych przewidywaniach przyszłości wymaga również odważnego spojrzenia w prawdopodobnie nastałe nowe realia. Taka wizja stanowi poważne utrudnienie. Nie dysponuję żadną ścisłą metodą naukową, która pozwoliłaby - z bardzo wysokim prawdopodobieństwem - na zbu-

${ }^{17}$ D. Urbaniak-Zając, Przemiany myśli społeczno-pedagogicznej w Niemczech, [w:] E. Marynowicz-Hetka (red.), Pedagogika społeczna. Debata, t. 2, Warszawa 2007, s. 366-377.

${ }^{18}$ E. Solarczyk-Ambrozik, Kształcenie ustawiczne w perspektywie globalnej i lokalnej. Między wymaganiami rynku a indywidualnymi strategiami edukacyjnymi, Poznań 2004, s. 16-17. Por. K. Segiet, K. Słupska, A. Tokaj, Etapy życiowe człowieka w kontekście pedagogiki społecznej, Poznań 2019. 
dowanie nie tyle obiektywnych, co w miarę wiarygodnych hipotez dotyczących rozwoju społecznego w wymiarze kolejnych dwóch/trzech dekad naszego stulecia i osadzenia (wkomponowania) na tym tle zadań oraz służebnej roli reprezentowanej przeze mnie i innych autorów subdyscypliny.

Przedstawiając sytuacje, które mogą wystąpić, a które w żadnym wypadku nie powinny być traktowane jako naukowo uzasadnione scenariusze rozwoju, nadmieniam, że to głównie dziennikarze przedstawiają od dawna pewien układ przewidywań - a ja głęboko ufam, że może się on ziścić i być realny. Na bazie przyjętych założeń upraszczających, które determinują i kreować będą nowy ład ekonomiczny, społeczny, kulturowy i edukacyjny w przybliżeniu przedstawię pojawiające się dywagacje. Najbardziej zbliżony wydaje się scenariusz wiążący się $\mathrm{z}$ dalszą stagnacją państw wysoko rozwiniętych i znaczącym wzrostem ludności w Afryce i Azji. To powiększy niewątpliwie aktualną lukę między najbiedniejszymi a najbogatszymi państwami świata (z obecną relacją $1: 50$ ) do niespotykanego wręcz rozmiaru $1: 80$ ). Przy przyjętym założeniu o ostatecznym obliczu globu ziemskiego oraz jego dynamice pozostawać będzie w gestii centralnych ośrodków i ogniw władzy gospodarczej, a być może w nieco mniejszym stopniu niż dotychczas - politycznej ${ }^{19}$.

Równocześnie być może odnotowujemy powstrzymywanie niektórych dzisiejszych zdrowotnie - traumatycznych tendencji rozwojowych (mam na myśli głównie pandemię, a to dzięki doświadczeniom i rozwojowi światowej medycyny publicznej). Świat może być zatem spowolniony, bardziej bierny w zakresie globalnego sterowania własną dynamiką rozwojową. Problemem zasadniczym jakże trudnym do rozwiązania staną się miejsca pracy. Ludzi w wieku tzw. produkcyjnym przybywać będzie znacznie więcej aniżeli dzisiaj. Ich liczba przekroczy oczywiście podaż oferowanych przez gospodarkę i administrację miejsc zatrudnienia. Regionalne bloki gospodarcze uwikłać się mogą w liczne - bliżej dzisiaj nierozpoznane - konfrontacje (żeby nie użyć słowa wojny) celno-handlowe. Być może powróci znany nam z przeszłości protekcjonizm, a o trybie i sposobie pozyskiwania subwencji/dotacji na rzecz pojawiających na świecie wielu projektów/programów zmierzających ku homeostazie publicznej, decydować będą wąskie gremia liderów gospodarczych, konkurujących ze sobą. Nieznana pozostaje, co dla nas jest szczególnie ważne, postać i kierunek przekształceń Unii Europejskiej po brexicie Wielkiej Brytanii. Sądzę też, że nastałe w kolejnych latach problemy społeczne, zdrowotne, ekologiczne, gospodarcze i niekorzystne ich trendy rozwojowe, o których

19 M. Ostrowski, A. Szostkiewicz, Świat 2001. Remanent, „Polityka” 2001, 6 stycznia, nr 1 (2279), s. 8; T. Pilch, Społeczeństwo obywatelskie wobec opresji i zniewolenia przez ideologie, polityke i władze, „Pedagogika Społeczna” 2018, nr 4 (70), s. 33-57; J. Modrzewski, Socjopedagogika. Studia szkice - refleksje - wspomnienia, Poznań 2016, s. 73-79. Por. A. Radziewicz-Winnicki, Pedagogika społeczna, op. cit., s. 544-548. 
wspominam, zaczną niepokoić coraz bardziej kręgi intelektualistów, naukowców, obywateli i samych polityków, co być może wyzwoli gotowość, tudzież zwiększoną aktywizacją publiczną, w prawie wszystkich częściach świata. W życiu społecznym nadal urzeczywistniać się będzie teza Ulricha Becka, że utożsamiani będziemy nadal ze „społeczeństwem ryzyka”, „zarówno w społeczeństwach rozwijających się, jak i postindustrialnych". Samo stwierdzenie nie wydaje się być już truizmem, bowiem wiele faktów dowodzi, że życie codzienne staje się bardziej ryzykowne, czego można doświadczać permanentnie i nieomal w każdej dziedzinie. Znana analiza wybitnego niemieckiego socjologa jest wiarygodna już obecnie i będzie aktualna - tak prognozujemy - w przyszłości. Więzi ideologiczne łączące klasy, warstwy i pewne środowiska nadal prawdopodobnie będą słabnąć, a nawet niektóre z nich zanikać. Stowarzyszenia, trwałe ongiś instytucjonalne związki, zakłady pracy, potężne korporacje stracą swoją siłę integrowania i jednoczenia - jak w przeszłości - grup i warstw całego społeczeństwa. W konsekwencji jednym z centralnych pojęć, którymi będzie można operować w psychospołecznych analizach, stanie się pojęcie ambiwalencji. Wszystkie przedstawione tu okoliczności zwiększą niewątpliwie potencjał wolnościowy jednostki, uwalniając ją od dość często uciążliwych związków o charakterze wzajemnych interakcji, ale równocześnie będą wymuszać podejmowanie samodzielnych decyzji. Coraz trudniejsze stanie się powierzenie własnego losu (a często, jak to współcześnie określamy, własnego „nieudanego życiorysu") trosce różnych instytucji społecznych czy np. stowarzyszeń, fundacji lokalnych o opiekuńczo-zaradczym charakterze. Powstać może groźna sytuacja, którą tylko nieliczne - nadzwyczaj sprawne i silne osobowości - mogą uznać za niepowtarzalną szansę rozwojową, inni zaś w zasadzie już postrzegają opisaną sytuację jako przykre doznanie bądź zagrożenie własne i swojej rodziny ${ }^{20}$.

Nawet nieprofesjonalne spojrzenie na początek bieżącego stulecia przywołuje barwną panoramę pełną wewnętrznych sprzeczności. Niewątpliwemu postępowi towarzyszy szereg współwystępujących powszechnie paradoksów. Nauka, podobnie jak cywilizacja jako jej pochodna, przeżywa okres nadzwyczajnego nigdy dotąd nienotowanego - rozwoju, z drugiej zaś strony rośnie liczba zjawisk, które wydają się pozostawać w wyraźnej sprzeczności z logiką rozwoju jakiejkolwiek struktury. Obok postępu dostrzegamy także katastrofy i liczne załamania w otaczającej jednostkę ludzką rzeczywistości. Fałsz, bezprawie, pragmatyzm czy też postęp są ze sobą ściśle powiązane. Przemieszane zostały wszelkie ideały współczesnych społeczeństw pochodzące z różnych konstelacji kulturowych i mentalnych.

${ }^{20}$ R. Sonntag, Urlich Beck i jego socjologiczne teorie drogi do innej nowoczesności, „Deutschland” 1997, nr 3, s. 19-21. Por. U. Beck, Społeczeństwo ryzyka. W drodze do innej nowoczesności, przekł. S. Cieśla, Warszawa 2002. 
Zróżnicowana opinia publiczna przejawia się w szeregu preferencyjnych opcji: od skrajnie liberalnych, przez ekonomiczną, socjalną fobię socjalistyczną, po zdecydowanie mieszaną, występującą w wielu różnorodnych warunkach, lecz za to przeważnie nieklarowną, reprezentującą poglądy raczej niespójne, zawierające swoiste compositum kilku często przeciwstawnych sobie alternatyw ideologicznych i gospodarczych ${ }^{21}$. Tego typu opcje polityczne, a nawet intelektualne spory, będą się prawdopodobnie nasilać w bliższej i dalszej przyszłości, podobnie jak w bieżącej dekadzie XXI wieku spory i animozje pomiędzy lewicą a prawicą znajdują jedynie wspólny mianownik w ufności co do prometejskiego mitu o ludzkiej mobilności i zdolności do przekształcania współczesnego społeczeństwa postindustrialnego na podstawie kolejnych umów społecznych. Miałaby to być kolejna ugoda między silnymi - posiadającymi udział we władzy i przywilejach - a słabymi współuczestnikami dokonujących się radykalnych przemian. Być może dzięki porozumieniu zwiększy się dotychczas często nikły udział w korzystaniu przez członków wielu grup z większości dobrodziejstw, jakie ma nieść za sobą wysoko rozwinięta gospodarka wolnorynkowa. Umowy społeczne zawsze pełnią rolę po części stabilizującą całe społeczeństwo. Są splotem praw i obowiązków między młodymi i starymi, bogatymi i biednymi, między pracodawcami a pracownikami. Mają utworzyć w miarę godne miejsce, własny situs przeciętnej jednostki w obrębie globalnego społeczeństwa, demokratycznego. Powszechne zainteresowanie w przyszłym postindustrialnym świecie wydaje się koncentrować na nieuniknionych następstwach nad wyraz szybko rozwijającej się biotechnologii oraz poważnych, a niekiedy trudnych do przewidzenia konsekwencjach wdrażania dotychczasowych rezultatów prowadzonych eksperymentów przez kolejne pokolenia. Stale aktualne pozostaną liczne pytania o następstwa dopuszczalnych eksperymentów i licznych przewartościowań, które wystąpią w obrębie podstawowych wzorców reakcji społecznych i politycznych w połowie XXI wieku ${ }^{22}$. Na tle prowadzonych dywagacji trudno nie wspomnieć o przyszłości Kościoła, którą upatrywać należy w sposób zróżnicowany i odmiennie kształtujący się w różnych częściach ziemskiego globu. Na ogół pluralizm kulturowy (występujący w Europie) oznacza już dzisiaj relatywizację tradycyjnej kościelności, albowiem pewne (nie zawsze nowe) interpretacje sensu życia podważają oczywistość zbawienia płynącą z nakazów bądź też bieżących zaleceń Kościoła. Pojawiające się orientacje oraz wzorce zachowań zalecane do powszechnego naśladowania są natury chrześcijańskiej lub (chociażby jak w przypadku licznych wyznawców buddyzmu) pozachrześcijańskiej. Są

${ }^{21}$ A. Miszalska, Wizja ładu społecznego w społeczeństwie postmonocentrycznym, „Kultura i Społeczeństwo" 1993, nr 3, t. XXXVII, s. 83-87.

${ }_{22}$ Perri 6, Nowe umowy społeczne w nadchodzacym stuleciu, „Deutschland” 1999, nr 6, s. 16-19. Peri 6 - brytyjski naukowiec (nauki społeczne). Zmienił nazwisko na Perri 6. Uprzednio posługiwał się imieniem i nazwiskiem David Aschworth. Autor kilkunastu książek. 
one, jak twierdzi ks. Janusz Mariański, również upowszechniane przez tzw. religie polityczne, a także głosicieli kultury niereligijnej. Wzrost podaży alternatywnych orientacji życiowych raczej osłabia dotychczasową tradycyjną pozycję Kościoła w obszarze edukacji światopoglądowej. Współczesny pluralizm religijny sprzyjać będzie raczej obojętności w sprawach wiary aniżeli pogłębieniu religijności. Deinstytucjonalizacji religijności nie należy w żadnym wypadku utożsamiać z drastycznym zanikiem religii, lecz z uwidaczniającą się przemianą form, w jakich religia (w trybie indywidualnym bądź zbiorowym) zacznie się objawiać23. Skoro w społeczeństwie pluralistycznym pod wpływem ogólnych zmian zaistniałych sytuacji społecznych w jakimś stopniu pogłębi się heterogenizacja postaw wobec nauki Kościoła, a tym samym różnicować się będą indywidualne orientacje życiowe, to oczekiwać można wzrostu roli reprezentantów nauk społecznych (w tym również pedagogów społecznych) w indywidualnym i zbiorowym kompensowaniu (nie potrafię określić, na ile rozległego kryzysu) przeżywania rewolucji etycznej, obyczajowej czy światopoglądowej. Jak wiemy, mity nowoczesności mogą prowadzić do alienacji, psychicznych marginalizacji, traumy/politraumy społecznej, a również i wykluczenia.

Przyszłość kojarzy się nam z możliwością udostępnienia wykształcenia wszystkim jej członkom. Informacje, wykształcenie i wiedza stają się - zgodnie z masowym kanonem przekazu - dobrem ogólnym, globalnym, które w dalszej perspektywie przyczyni się do stworzenia szans, a co ważniejsze, redukcji niebezpiecznych przecież nierówności. W obliczu rozlicznych, stale artykułowanych wyzwań, wielowymiarowe cele i zadania edukacji jawić się będą nadal jako podstawowa szansa, którą należy bezwzględnie wykorzystać w dążeniu ludzkości do ideałów pokoju, wolności, egalitaryzmu i sprawiedliwości oraz pomyślności społecznej24.

Niewątpliwie wystąpią dalsze zakłócenia nie tylko w krajowym, ale także na światowym rynku pracy. Powrót do koncepcji klasycznego (pełnego) zatrudnienia wydaje się być - w świetle bieżących prognoz ekonomicznych - raczej niemożliwym, złudnym i wręcz utopijnym marzeniem, o czym wspomniano już uprzednio. Wśród wielu koncepcji przeciwdziałających potęgującym się perturbacjom na uwagę zasługuje jedna $\mathrm{z}$ nich, tj. szczególnie radykalna wizja przebudowy społeczeństwa pracy w powiązaniu z opracowaniem określonej strategii inicjacji zawodowej dla młodzieży ${ }^{25}$. Praca obywatelska i lokalne giełdy wymiany pracy to także jedna $\mathrm{z}$ kilku interesujących alternatyw podejścia do znanego nam tradycyjnego modelu pracy zawodowej. Ich losy z doświadczeń podejmowanej pracy wielu grup

${ }^{23}$ J. Mariański, Młodzież między tradycją a nowoczesnościa, Lublin 1999, s. 89-90.

${ }^{24}$ R.D. Hochleitner, Ścieżki nadziei i jej perspektywy: jak będziemy żyć jutro?, „Deutschland” 1999, nr 6, s. 12-13.

${ }^{25}$ Z. Wołk, Zawodoznawstwo. Wiedza o wspótczesnej pracy, Warszawa 2013, s. 187-196. Por. R. Tomaszewska-Lipiec, Praca zawodowa - życie osobiste. Dysonans czy synergia?, Bydgoszcz 2018. 
ludności, zwłaszcza w krajach wysoko rozwiniętych, ulegną zatem z pewnością zmianie. Pracę pełnoetatową ( $\mathrm{z}$ racji stale rosnącej wydajności i postępu technologicznego) zastąpi praca w niepełnym wymiarze godzin. Przed stu laty ludzie poświęcali blisko 35\% swojego życia pracy zawodowej. Dzisiaj stanowi ona niecałe 13\%, a w nieodległej przyszłości - tak twierdzą współcześni ekonomiczni planiści - praca zarobkowa stanowić będzie zaledwie $6 \%$ ogólnego udziału w dłuższym o kilka lat życiu człowieka. Aby zwiększyć satysfakcjonujący udział pojedynczego obywatela w pomyślnym rozwoju zarówno całego społeczeństwa, jak i społeczności lokalnej, zaleca się, aby w jego własnej zagospodarowanej rodzinnie przestrzeni upatrywać podstawową jednostkę organizacyjno-gospodarczą. Tak więc prywatne gospodarstwo domowe ma się stać nie tylko miejscem konsumpcji i spędzania czasu wolnego, ale również - w świetle przewidywań - przekształci się w ważne miejsce produkcji wykonywania pracy własnej, świadczenia usług, niesienia pomocy itp. Owa metamorfoza za sprawą nowo powstających technologii w sytuacji permanentnego wzrostu budżetu czasu wolnego wykorzystywanego nie tylko na wypoczynek może sprzyjać niespotykanemu dotąd rozkwitowi gospodarstw domowych. Zasoby wiedzy - inaczej niż kapitału i pracy - są w zasadzie niewyczerpane, tymczasem klasyczna ekonomika wolnorynkowa zaczyna się stawać nieco przestarzała, skoro z uporem zajmuje się przede wszystkim alokacją zasobów limitowanych i ograniczonych. Może więc już w nie tak odległej przyszłości utracić swoją dotychczasową pozycję i wiarygodność. W nowo tworzącej się na szczeblu komunalnym rzeczywistości potrzebni natomiast będą konsultanci - partnerzy i koordynatorzy (m.in. pedagodzy społeczni) do prowadzenia ścisłej współpracy z mieszkańcami środowisk lokalnych po to, aby zróżnicowany zakres ofert pracy odpowiadał potrzebom różnych grup obywateli. Zakładać można, iż w nieodległej już przyszłości w ramach ewolucji aktywnego i mobilnego społeczeństwa obywatelskiego utworzona zostanie nowa integracyjna i atrakcyjna zarazem infrastruktura pracy na rzecz ogółu, stwarzająca wolność wyboru różnych modeli życia oraz możliwości wyrażania poprzez udział w życiu publicznym własnej niepowtarzalnej tożsamości jednostki o jej szczególnym pluralistycznym i zróżnicowanym charakterze. Główną ideą nowego przyszłego systemu społeczno-zabezpieczającego, egzystującego w praktyce codziennej służby, będzie stworzenie z pewnością takiej formy powszechnego ubezpieczenia (zabezpieczenia) publicznego, aby można było zredukować (a docelowo wyeliminować) znaczenie działalności misyjnej, charytatywnej bądź dobroczynnej na rzecz profesjonalnych i wysoce cywilizowanych służb pragmatycznie oraz sprawnie wykonujących swoje obowiązki ${ }^{26}$.

${ }^{26}$ H. Sagier, Od pracy zarobkowej do społeczeństwa obywatelskiego, „Deutschland” 1999, nr 6, s. 44-45; zob. M. Piorunek (red.), Społeczne i jednostkowe konteksty pomocy, wsparcia społecznego i poradnictwa. Koncepcje - Dyskursy - Inspiracje, t. 1, Poznań 2019. 
Jestem przekonany o szczególnej przydatności pedagogów społecznych i reprezentowanej przez nich subdyscypliny w wielowymiarowych sytuacjach (wiążących się z ideą kreowania ogólnego dobrostanu i obowiązkiem podejmowania licznych przedsięwzięć na rzecz trwania ładu i porządku publicznego). Można identyfikować zaledwie niektóre przykłady szczegółowych problemów spośród rozlicznych zadań i obowiązków, a także wyodrębnionych powinności, które można byłoby powierzyć tym specjalistom. Do nich należałoby m.in. diagnozowanie potrzeb, oczekiwań i wielu trudnych, wrażliwych i pilnych kwestii (dotyczących środowisk ludzi marginalizowanych), a równocześnie tworzenie ram społecznego nadzoru dla ich pomyślnej kompensacji; artykułowanie i identyfikowanie potrzeb, uchybień, nieprawidłowości oraz interesów lokalnej społeczności, przedstawiając je odpowiednim organom władz samorządowych, państwowych itp. w celu podejmowania rozstrzygnięć prowadzących ku homeostazie społecznej; formułowanie różnych planów rozwoju (w tym również alternatywnych wizji przekształceń), które przy aprobacie lokalnej społeczności i decyzjach władz przybiorą postać instytucjonalnie asymilowanej innowacji, powszechnie akceptowanej wraz z wprowadzeniem skutecznego programu wdrożenia określonej funkcji edukacyjnej (i samoedukacyjnej) wśród mieszkańców społeczności lokalnej (regionu), wiążącej się z socjalizacją wielu podopiecznych (klientów), w tym prowadzenie aktywnych konsultacji z zakresu teorii i praktyki poradnictwa (doradztwa), również zawodowego; stymulowanie rozwoju (socjalizacja kulturowa), a tym samym kształtowanie kultury adekwatnej do kolejnego etapu przeobrażeń społeczeństwa obywatelskiego XXI wieku, m.in. poprzez stymulowanie uczestnictwa w wielu zespołach, komitetach, stowarzyszeniach czy innych lokalnych grupach formalnych (nieformalnych) o zadaniowym charakterze grup inicjatywnych, odpowiedzialnych (współodpowiedzialnych) za zagospodarowanie różnych sfer (głównie pozakomercyjnych), wiążących się z kreowaniem pomyślnego bytu jednostki na zlokalizowanym obszarze egzystencji miejscowych struktur ludności itp.

W zakończeniu wspominam wyłącznie o przyszłej roli pedagogiki społecznej jako dziedziny wiedzy użytecznej i stosowanej w praktyce życia codziennego, pomijając oczywistą dalszą profesjonalizację tej subdyscypliny na płaszczyźnie prowadzonych badań naukowych. Nie wykluczam jednakże, a wręcz skłaniam się ku poglądowi, iż poszukując lepszych, odmiennych od dotychczasowych form kształcenia w akademickim szkolnictwie wyższym, które pozostaną w oczywistej korelacji z licznymi ograniczeniami występującymi na lokalnych rynkach pracy, może dojść do fuzji (a więc komasacji) niektórych kierunków studiów w ramach ogólnego profilu kształcenia występującego na gruncie nauk społecznych. Dostrzegamy przecież już obecnie radykalne kurczenie się globalnej liczby etatów, np. pedagogów szkolnych, psychologów czy socjologów, oferowanych przez poszczególne instytucje i dostępnych w różnych sferach życia publicznego. Doświadczamy stale powiększających się 
dysproporcji między edukacją a zatrudnieniem, która to sytuacja dotyka absolwentów kilku dyscyplin nauk społecznych. Ponadto mamy do czynienia ze wzrastającym kosztem kształcenia akademickiego, a więc funduszami, które nawet bogatsze niż Polska państwa Unii Europejskiej są w stanie przeznaczyć i zainwestować w szkolnictwo wyższe. W tej sytuacji być może w kształceniu reprezentantów nauk spolecznych zacznie się nawiązywać do zasadności stosowania modelu interwencyjno-eksperckiego w poznawczej i socjotechnicznej praktyce życia ${ }^{27}$. Oczywiście w formie zmodyfikowanej uwzględniającej przyszłe, a nie obecne realia naszej współczesności. To propozycja (alternatywa) scalenia tak w sferze nauki, jak i praktyki publicznej. Skłaniam się od szeregu lat ku poglądowi, iż poszukując lepszych, optymalnych rozstrzygnięć, które pozostają w oczywistej korelacji z licznymi perturbacjami zatrudnienia humanistów na lokalnych rynkach pracy, w ramach prowadzonej dyskusji (przedporozumienia) można byłoby eksperymentalnie wprowadzić nowy - zintegrowany kierunek kształcenia pedagogów, socjologów oraz psychologów ${ }^{28}$. Model, o którym wspominam, zapoczątkowany został przez humanistów skandynawskich (jeszcze w latach 60 . ubiegłego wieku) i polegał m.in. na samorzutnym rozpoznawaniu przez socjologów (ale również reprezentantów innych dyscyplin) ważnych problemów społecznych, zbiorowym proponowaniu podjęcia określonych rozwiązań i uczestniczeniu ekspertów w ich ostatecznym rozstrzyganiu ${ }^{29}$. W przyszłości przy takiej zbiorczej formie kształcenia badania nad zmianami wśród czynników instytucjonalnych, ekonomicznych, kulturowych, wychowawczych itp. mógłby prowadzić magister nauk społecznych, reprezentujący określoną specjalność/podspecjalność zawodową (pedagogikę, socjologię, psychologię itp.). Niezależnie od przyjętych w przyszłości rozwiązań pedagog społeczny już dzisiaj musi pretendować do tego, aby uchodzić za wiarygodnego, bezstronnego arbitra w wielu podstawowych kwestiach, którymi zajmują się nauki społeczne, chociaż ze względów oczywistych najbliższe z pewnością pozostają kwestie tematyczne realizowane $\mathrm{w}$ programie studiów z obszarów: socjalizacji i wychowania, opieki czy też pracy socjalnej ${ }^{30}$.

$\mathrm{W}$ żadnym przypadku przy konwencjonalnie przyjętych zmianach nie będzie można podważać autonomii naszej subdyscypliny jako intelektualnego podmiotu poznającego. Opisana powyżej sytuacja prawdopodobnych zmian w sygnalizowanych formach kształcenia nie będzie dotyczyć przyszłego, zapewne interesującego

${ }^{27}$ K. Marzec-Holka, A. Radziewicz-Winnicki, A. Wiłkomirska, Nauki społeczne wobec zmianyalternatywa scalania (inspiracje dla współczesnej pedagogiki), Warszawa 2018, s. 12-13.

28 A. Radziewicz-Winnicki, Przedporozumienie jako kategoria teoretyczna w zakresie scalania wielu subdyscyplin zajmujących się wsparciem, pomocniczościa, poradnictwem i rehabilitacją publicz$n q$, referat wygłoszony podczas V ogólnopolskiej Konferencji Naukowej pt. „Pomoc - wsparcie społeczne - poradnictwo" Poznań, 25.03.2021, WSE UAM, s. 14-16.

29 J. Kwaśniewski, Socjologia stosowana, [w:] Encyklopedia Socjologii, t. 4, Warszawa 2002, s. 82.

${ }^{30}$ A. Radziewicz-Winnicki, Pedagogika społeczna, op. cit., s. 550. 
uzawodowienia kolejnych ofert edukacyjnych i dalszych pragmatycznych kontaktów oraz współpracy szkół wyższych z władzami lokalnymi i z sektorem gospodarczym, jak również z innymi organizacjami obywatelskimi w okresie nasilonej ekspansji edukacyjnej licznych ośrodków akademickich na naszym kontynencie. Specyfika tradycyjnej misji, związana z działalnością usługową prowadzoną w przyszłości, obecnie jest bardzo trudna do określenia. Aktualnie tendencje rozwojowe pozwalają przewidywać, że politechniki będą się starały raczej intensywnie rozwijać badawczą działalność usługową, natomiast akademie pedagogiczne (wyższe szkoły pedagogiczne) prowadzić będą różnego typu działania dostosowane do oczekiwań otoczenia (głównie lokalnego) społecznego, polegające m.in. na wprowadzaniu wielu odpłatnych zróżnicowanych form kształcenia na poziomie wyższym, w tym również studiów podyplomowych.

W przypadku uniwersytetów najprawdopodobniej - tak dawno już sygnalizowała Elżbieta Wnuk-Lipińska - nastąpi dalsze wewnętrzne zróżnicowanie na jednostki organizacyjne nastawione bardziej na realizację funkcji badawczych oraz - podobnie jak w przypadku wyższych szkół pedagogicznych - na intensyfikację zadań edukacyjnych ${ }^{31}$.

Prowadzone analizy jednoznacznie sugerują, że pedagogika społeczna, zachowując własną tożsamość, podlegać będzie dalszym modyfikacjom, których źródła upatrywać należy $\mathrm{w}$ dynamice wielu procesów społeczno-kulturowych i ciągłym gromadzeniu nabywanej i uaktualnianej wiedzy ${ }^{32}$.

Jakikolwiek pesymizm na zakończenie niniejszych polemicznych po części rozważań nie byłby na miejscu. Zaawansowane społeczeństwo XXI wieku musi sobie poradzić z wszelkimi zmianami i własnym w pełni nierozeznanym jeszcze impetem. Pedagogika społeczna - jak i inne dyscypliny - stając u progu kolejnych trudnych wyzwań, musi rozwiązać także inny palący problem, eksplodujący jak nigdy dotąd ilością nagromadzonej i nowo powstałej wiedzy. Pomimo rewolucyjnych przemian stale trzeba będzie powracać - tak jak i w naszym czasie społecznym - do psychospołecznego wymiaru przebiegającego procesu zmiany i postępu. Tak jak w chwili bieżącej zapewne nadal będą dostrzegane nieuchronne przecież konflikty i napięcia, animozje wpływające na samopoczucie jednostek i grup społecznych, a wiele osób odczuwać będzie znaną naszemu pokoleniu lub też jakąś nieznaną formę społecznej, politycznej i ekonomicznej degradacji.

31 E. Wnuk-Lipińska, Innowacyjność a konserwatyzm. Uczelnie polskie w procesie przemian społecznych, Warszawa 1996, s. 63-66.

32 J. Piekarski, U podstaw pedagogiki społecznej. Zagadnienia teoretyczno-metodologiczne, Łódź 2007, s. 304. 
Działania profilaktyczne, kompensacyjne, organizowanie adekwatnych do poszczególnych realiów form pomocy, samopomocy, animacji, aktywności, które pozwalają tworzyć takie typy idealne dla formułującego się społeczeństwa jutra, które stanowić będą dla jednostki społeczeństwo w pełni przyjazne. Jak zawsze oczekiwany i nieoczekiwany (życiowy) rozwój dokona się na drodze kolejnych eksperymentów. Zarysowane możliwości przekształcą być może świadomość społeczną i wiedzę o nas samych jeszcze bardziej precyzyjnie i dogłębnie niż dotychczas za sprawą naukowej wiedzy, ofiarując przyszłym pokoleniom zweryfikowane uprzednio trafne, wiarygodne i poprawne nowe rozwiązanie praktyczne. Na sam koniec pragnę przytoczyć interpretacje sieci społecznej (social network) Andrzeja Olubińskiego oraz Tadeusza Sozańskiego, które powinny pozostawać dla pedagogów społecznych dwóch/trzech pokoleń naczelną dewizą dla ich mobilności i aktywizacji publicznej.

To tworzenie określonego układu stosunków, norm i wartości przez członków społeczności lokalnej niezależnie od reprezentowanych przez nich norm kulturowych. Może właśnie ona egzemplifikuje tezy Heleny Radlińskiej o uruchamianiu sił społecznych w środowiskach lokalnych i ich potencjalne możliwości wykorzystania w rozwoju środowisk lokalnych ${ }^{33}$.

(...) to szeroki zakres interakcji zachodzących między członkami rozmaitych zbiorowości społecznych. Ta bardzo szeroka klasa zjawisk obejmuje postawy, oceny, uczucia ludzi względem innych ludzi, komunikowanie się bezpośrednie i pośrednie, wspólne działania związane z realizacją celu grupowego, jednostronne i dwustronne przepływy zasobów, pokrewieństwo, wpływ interpersonalny, naśladownictwo i „zarażanie się" chorobami, modą, ideami, innowacjami, różne stosunki przestrzenne interesujące ekologię społeczną (bliskość w przestrzeni fizycznej lub społecznej) i stosunki społeczne z nimi związane (np. sąsiedztwo), władze wszelkiego typu, stosunki podległości i nadrzędności w organizacjach (stosunki między pozycjami i rolami).

Sieć prosta składa się z obiektów tego samego rodzaju, między którymi występują diadyczne związki tego samego typu tworzące relację dwuargumentową. W sieciach złożonych dopuszcza się niejednorodność zbioru elementów oraz równoczesne występowanie powiązań różnego typu ${ }^{34}$.

W takiej to właśnie przytoczonej interpretacji przedkładam Czytelnikom własną wiarę w renesans i odnowę pedagogiki społecznej w kolejności prowadzonych sekwencji na rzecz wzmożenia oczekiwanych przez nas pomocowych interakcji społecznych. Przygotowanie do druku niniejszego tomu dowodzi o twórczej

33 A. Olubiński, Problematyka sił społecznych środowiska wychowawczego (wprowadzenie do koncepcji), „Ruch Prawniczy, Ekonomiczny i Socjologiczny” 1983, z. 4, s. 257-259.

${ }^{34}$ T. Sozański, Sieć społeczna, [w:] Encyklopedia Socjologii, t. 4, Warszawa 2002, s. 28-29; zob. T. Lewowicki, E. Ogrodzka-Mazur, B. Chojnacka-Szyszko, U. Klajmon-Lech (red.), Spheres of Spiritual Life - A Study on Permenence and Changeability of Identity Behaviours in Borderland Communities, Munich 2018. 
samorealizacji jego autorów, a nade wszystko inspiratorów - Redaktorów Naczelnych tomów - starego (jeszcze w tradycyjnej postaci) - Tadeusza Pilcha, Wiesława Theissa - oraz nowego oblicza periodyku przygotowanego do druku pod opieką Katarzyny Segiet. Zwracam przy tym uwagę na rolę wymienionych postaci pozapolitycznych agentów na rzecz wdrożenia pewnych idei proponowanej przemiany, innowacji zmiany i prowadzenia systematycznej kampanii o charakterze postulatywno-naprawczym ${ }^{35}$. Mam na myśli propozycje pragmatycznych rozstrzygnięć dedykowane wszystkim kreatorom życia społecznego nie tylko pojawiającym się w najbliższej nam bezpośrednio przestrzeni, które stanowić być może będą potężną i realną siłę motywacyjną zbliżającą nas ku realnej nowoczesności, a więc renesansu publicznego.

\section{Bibliografia}

Altman, I. The Environment and Social Behavior: Privacy, Personal Space, Territory, Crowding, Monterey, California 1975.

Beck U., Społeczeństwo ryzyka. W drodze do innej nowoczesności, przekł. S. Cieśla, Warszawa 2002.

Cobel-Tokarska M., Przestrzeń społeczna: świat - dom - miasto, Warszawa 2011.

Gouldner A.W., Co zdarzyło się w socjologii. Historyczny model rozwoju strukturalnego, [w:] J. Szacki (red.) Czy kryzys socjologii?, Warszawa 1977.

Harding A., Blaxland T., Urban Theory. A Critical Introduction to Power, Cities and Urbanism in $21^{\text {st }}$ Century, Los Angeles-London-New Delhi-Singapore-Washington DC 2014.

Hochleitner R.D., Ścieżki nadziei i jej perspektywy: jak będziemy żyć jutro?, „Deutschland” 1999, nr 6. Hull Z., Wstęp. W poszukiwaniu prawdy o człowieku, [w:] W. Tulibacki, Z. Frydryszek (red), O literaturze i filozofii. Problemy - Twórcy - Dzieła, Olsztyn 1999.

Jacko J.F., Nimb aksjologiczny. Uwagi o etycznych aspektach przestrzeni osobistej, „Ethos” 2013, nr 4. Jóźko M., Społeczeństwo obywatelskie w małym mieście, „Kultura i Społeczeństwo” 2002, nr 3, t. XLVI. Krysiński D., Banaś J., Między nieudaną prowokacją a modelowa integracją. O renesansie aktywizacji społecznej w wydaniu artystycznym, „Kultura i Społeczeństwo” 2018, nr 3, t. LXII.

Kurnicki K., Ideologie w mieście: o społecznej produkcji przestrzeni, Kraków 2018.

Krzysztofek K., Szczepański M.S., Rozwój społeczny. Trzy paradygmaty, „Kultura i Społeczeństwo” 1987, nr 3, t. XXI.

Kwaśniewski J., Socjologia stosowana, [w:] Encyklopedia Socjologii, t. 4, Warszawa 2002.

Lewowicki T., Ogrodzka-Mazur E., Chojnacka-Szyszko B., Klajmon-Lech U. (red.), Spheres of Spiritual Life - A Study on Permenence and Changeability of Identity Behaviours in Borderland Communities, Munich 2018.

Mariański J., Młodzież między tradycją i ponowoczesnością, Lublin 1999.

${ }^{35}$ A.W. Gouldner, Co zdarzyło się w socjologii. Historyczny model rozwoju strukturalnego, [w:] J. Szacki (red.) Czy kryzys socjologii?, Warszawa 1977, s. 127-255. Por. A. Rychard, Parę refleksji o trudnościach tworzenia krytycznej socjologii postkomunizmu, „Studia Socjologiczne” 2007, nr 1, s. $49-50$. 
Marzec-Holka K., Radziewicz-Winnicki A., Wiłkomirska A., Nauki społeczne wobec zmiany - alternatywa scalania (inspiracje dla współczesnej pedagogiki), Warszawa 2018.

Matysiak-Błaszczyk A., Modrzewski J. (red.), Socjalizacja dysocjacyjna w doświadczeniu indywidualnym i społecznym. Inspiracje teoretyczne i próby pedagogicznych ingerencji, Poznań-Kalisz 2012.

Mendel M., Theiss W., Pamięć i miejsce ,in potentia”: o mieście pełnym, „Pedagogika Społeczna” 2016, nr 1 (59).

Mieszalska A., Wizja ładu społecznego w społeczeństwie postmonocentrycznym, „Kultura i Społeczeństwo" 1993, nr 3, t. XXXVII.

Modrzewski J., Matysiak-Błaszczyk A., Włodarczyk W. (red), Środowiska uczestnictwa społecznego jednostek, kategorii i grup (doświadczenia socjalizacyjne i biograficzne), Poznań 2018.

Modrzewski J., Socjopedagogika. Studia - szkice - refleksje - wspomnienia, Poznań 2016.

Modrzewski J., Z(dez)integrowane społeczeństwa - istota zjawiska i problemu w perspektywie strukturalno- funkcjonalnej, „Pedagogika Społeczna” 2017, nr 4 (66).

Odrodzenie, [w:] Encyklopedia Powszechna PWN, Warszawa 1982.

Olubiński A., Problematyka sił społecznych środowiska wychowawczego (wprowadzenie do koncepcji), „Ruch Prawniczy, Ekonomiczny i Socjologiczny” 1983, z. 4.

Ostrowski M., Szostkiewicz A., Świat 2001. Remanent, „Polityka” 2001, 6 stycznia, nr 1 (2279).

Perri 6, Nowe umowy społeczne w nadchodzacym stuleciu, „Deutschland” 1999, nr 6.

Piekarski J., U podstaw pedagogiki społecznej. Zagadnienia teoretyczno-metodologiczne, Łódź 2007.

Pilch T., Społeczeństwo obywatelskie wobec opresji i zniewolenia przez ideologie, politykę i władzę, „Pedagogika Społeczna” 2018, nr 4 (70).

Piorunek M. (red.), Społeczne i jednostkowe konteksty pomocy, wsparcia społecznego i poradnictwa. Koncepcje - Dyskursy - Inspiracje, t. 1, Poznań 2019.

Podemski K., Społeczeństwo obywatelskie w Polsce 25 lat po wielkiej zmianie, „Ruch Prawniczy, Ekonomiczny i Socjologiczny" 2014, z. 2.

Radziewicz-Winnicki A., Pedagogika społeczna, Warszawa 2008.

Radziewicz-Winnicki A. Przedporozumienie jako kategoria teoretyczna w zakresie scalania wielu subdyscyplin zajmujacych się wsparciem, pomocniczością, poradnictwem i rehabilitacją publiczną, referat wygłoszony podczas V ogólnopolskiej Konferencji Naukowej pt. „Pomoc - wsparcie społeczne - poradnictwo" Poznań, 25.03.2021, WSE UAM.

Rychard A., Parę refleksji o trudnościach tworzenia krytycznej socjologii postkomunizmu, „Studia Socjologiczne" 2007, nr 1.

Sagier H., Od pracy zarobkowej do społeczeństwa obywatelskiego, „Deutschland” 1999, nr 6.

Schmalz-Bruns R., Civil Society-ein postmodernes konstprodukt? Eine Antwort auf volker Heins, „Politische Vierteljahresschrift" 1992, (33), z. 2.

Segiet K., O społecznościach lokalnych i wspólnotach ludzkich w warunkach globalizacji-perspektywa pedagogiczna, „Kultura - Społeczeństwo - Edukacja” 2020, nr 1 (17).

Segiet K., Słupska K., Tokaj A., Etapy życiowe człowieka w kontekście pedagogiki społecznej, Poznań 2019.

Smolińska-Theiss B., Pedagogika społeczna - pedagogika społecznie zaangażowana wokót inicjatyw i ruchów społecznych, „Pedagogika Społeczna” 2018, nr 4 (70).

Solarczyk-Ambrozik E., Kształcenie ustawiczne w perspektywie globalnej i lokalnej. Między wymaganiami rynku a indywidualnymi strategiami edukacyjnymi, Poznań 2004.

Sonntag R., Urlich Beck i jego socjologiczne teorie drogi do innej nowoczesności, „Deutschland” 1997, nr 3 . 
Sozański T., Sieć społeczna, [w:] Encyklopedia Socjologii, t. 4, Warszawa 2002.

Szacka B., Wprowadzenie do socjologii, Warszawa 2003.

Szafraniec K., Anomia, [w:] Encyklopedia Socjologii, t. 1, Warszawa 1998.

Szczurek-Boruta A., Chojnacka-Synaszko B., Suchodolska J. (red.), Człowiek w przestrzeni lokalnejdobre praktyki wspierania rozwoju, aktywizacji i integracji społecznej, Toruń 2014.

Sztompka P., Socjologia. Analiza społeczeństwa, Kraków 2002.

Theiss W., Radlińska, Warszawa 1997.

Tomaszewska-Lipiec R., Praca zawodowa - życie osobiste. Dysonans czy synergia?, Bydgoszcz 2018.

Urbaniak-Zając D., Przemiany myśli społeczno-pedagogicznej w Niemczech, [w:] E. Marynowicz-Hetka (red.), Pedagogika społeczna. Debata, t. 2, Warszawa 2007.

Wilk T., Rewitalizacja społeczna poprzez wspótczesna sztukę teatralna w ocenie reprezentantów (twórców i odbiorców) sztuki dramatycznej Legnicy, Nowej Huty, Wałbrzycha, Katowice 2010.

Wnuk-Lipińska E., Innowacyjność a konserwatyzm. Uczelnie polskie w procesie przemian społecznych, Warszawa 1996.

Wołk Z., Zawodoznawstwo. Wiedza o współczesnej pracy, Warszawa 2013. 